ности, предложены подходы к выяснению последовательности и одновременности события-причины и события-следствия в криминалистике.

Ключевые слова: асимметрия причинно-следственной связи, асимметрия временного отношения, последовательность события-причины и события-следствия, временной признак причинно-следственной связи.

\title{
TEMPORAL SIGN OF CAUSE AND EFFECT RELATIONSHIP IN CRIMINALISTICS
}

Velikanov $S$. $\boldsymbol{V}$.

The paper deals with the temporary sign whose study in criminalistics and other branches of knowledge is an important element of establishing causal relationship between the events. Logic and philosophical foundations as a sequence and simultaneity of the cause and effect are studied. Herewith, it's taken into account that the asymmetrical arrangement of the cause which is chronologically before the consequence, is based on the everyday perception of time by which the time movement occurs in one direction, from the past through the present to the future and the time flow coincides with the passage of causality. The correlation between the above indicated provisions to the legal notions on causality is substantiated. Just as in the Civil Law a particular legal fact precedes the emergence of the legal consequences in the formation of legal relationship, and as in the Criminal Law an act is located before the criminal consequences for the crimes with the material composition, in criminalistics it's considered that the traces of a crime are formed as a result of the foregoing mechanical, thermal, chemical, biological, et al. interactions. The paper proposes a criminalistic approach to the temporary sign of the cause and effect relationship consisting of the following elements: 1) the asymmetry of following of event-cause and event-consequence, the cause precedes the effect, and not otherwise; 2) a causal complex of event-cause is performed within the range of causing, and the consequence requires time for the formation; 3) the time scale of cause and effect should coincide in the degree of generality. The form of the considered approach is presented graphically, and application of the outlined approach provisions is discussed on a practical example of the court sentence plot.

Keywords: asymmetry of the cause and effect relationship, asymmetry of the temporary relationship, the sequence of the event-cause and event-consequence, temporary sign of the cause and effect relationship.

УДК 343.98

B. А. Фастовець, співробітник Служби безпеки України, кандидат юридичних наук

\section{ПРОБЛЕМНІ ПИТАННЯ ЩОДО ОТРИМАННЯ ПОКАЗАНЬ ВІД ОБІЗНАНИХ ОСІБ}

Досліджено окремі питання щуодо отримання показань від обізнаних осіб (носїв спеціальних знань) у кримінальному провадженні. Виявлено недоліки правозастосовної діяльності щодо процесуального оформлення таких показань, які суперечать вимогам чинного кримінального прочесуального

(C) Фастовець В. А., 2016 
законодавства. Надано власні пропозииї стосовно внесення змін до Кримінального прочесуального кодексу Украӥни.

Ключові слова: Кримінальний процесуальний кодекс Украӥни, допит, експерт, спечіаліст, обізнаний свідок, обізнана особа.

Серед недоліків Кримінально-процесуального кодексу України 1960 р. як практичні співробітники, так і науковці досить часто виокремлювали приділення недостатньої уваги правовій регламентації особливостей використання спеціальних знань у кримінальному процесі. Водночас, незважаючи на прогресивний характер прийнятого у 2012 р. Кримінального процесуального кодексу України ${ }^{1}$ (КПК України), цим нормативно-правовим актом зазначені питання також не були вирішені. Це стосується насамперед деяких моментів процесуального оформлення відомостей, отриманих на стадії досудового розслідування або судового розгляду від експерта або спеціаліста, які залучалися до участі в слідчих (розшукових) або інших процесуальних діях, а також від обізнаних осіб (носіїв спеціальних знань), які попередньо не залучалися до кримінального провадження.

Аналіз правозастосовної практики свідчить про відсутність єдиного підходу до розгляду зазначених питань. Так, значна частина практичних працівників органів досудового розслідування оформлює факт отримання таких відомостей шляхом допиту носіїв спеціальних знань як спеціалістів. Інші вважають, що допит таких суб'єктів саме як свідків більшою мірою відповідатиме чинному кримінальному процесуальному законодавству. Слід зазначити, що вказані обставини не сприяють єдиній правозастосовній діяльності та в окремих випадках можуть не узгоджуватися 3 нормами чинного законодавства. Про складність цієї ситуації свідчить і наявність полярних думок та відсутність єдиної позиції з цього приводу також і серед науковців.

Питанням використання спеціальних знань у кримінальному процесі приділено чимало уваги з боку вітчизняних науковців, зокрема О. О. Бондаренка, А. Ф. Волобуєва, І. В. Пирога, В. Д. Понікарова, В. М. Реваки, В. В. Семенова та ін. Зазначена тематика також знайшла своє відображення в наукових працях таких учених, як Г. І. Грамович, А. В. Дулов, Ю. О. Калінкін, В. М. Махов, О. В. Селіна, I. М. Сорокотягін, І. Я. Фойницький. Однак цими дослідниками не досягнуто спільної точки зору щодо особливостей отримання показань від обізнаних осіб. Крім того, їх висновки зроблені без урахування реформованого вітчизняного кримінального процесуального законодавства.

Отже, метою статті є аналіз норм чинного КПК України, виявлення недоліків правової регламентації порядку отримання показань від носіїв спеціальних знань, а також формулювання власних пропозицій щодо вирішення виявлених проблемних питань.

Безумовно, важливість участі обізнаних осіб у рамках кримінального провадження складно переоцінити. Зокрема, експерт проводить дослідження об’єктів, явищ і процесів, що містять відомості про обставини вчинення

\footnotetext{
${ }^{1}$ Див.: Кримінальний процесуальний кодекс України. - К. : Центр учбов. л-ри, 2012. -254 c.
} 
кримінального правопорушення, й дає висновок із питань, які виникають під час кримінального провадження та стосуються сфери його знань. Особа, яка володіє спеціальними знаннями та навичками застосування технічних або інших засобів, може залучатися в кримінальному провадженні як спеціаліст із метою надання консультацій під час досудового розслідування чи судового розгляду з питань, що потребують відповідних спеціальних знань i навичок, або з метою надання безпосередньої технічної допомоги (фотографування, складення схем, планів, креслень, відбір зразків для проведення експертизи тощо).

У процесі залучення цих суб'єктів вони нерідко повідомляють відомості стосовно окремих обставин, що мають значення для кримінального провадження. Як правило, ці відомості являють собою позицію (думку, бачення) носіїв спеціальних знань з приводу певних об’єктів, явищ і процесів та можуть бути використані слідчим або суддею як для вирішення питань організаційного (наприклад, щодо визначення переліку документів, необхідних для проведення ревізії або порядку відібрання зразків для проведення експертного дослідження тощо), так і тактичного характеру (наприклад, визначення черговості проведення слідчих (розшукових) дій, оцінювання обгрунтованості висновків експерта або показань учасників кримінального провадження тощо).

Водночас досить часто виникає необхідність використання таких відомостей носіїв спеціальних знань у процесі доказування. Зазначене $\epsilon$ взаємопов' язаним 3 питанням «уведення» слідчим або суддею таких відомостей до кримінального процесу, тобто - 3 процедурою їх процесуального оформлення.

Як уже згадувалося серед учених не склалося єдиної позиції щодо можливості проведення допиту осіб, які володіють спеціальними знаннями. Зокрема, такі вітчизняні дослідники як В. В. Семенов, О. О. Бондаренко ${ }^{1}$ визнають можливість і доцільність проведення допиту обізнаних осіб. Поділяють цю позицію й чимало інших науковців, а саме: Г. І. Грамович, А. В. Дулов, Ю. О. Калінкін, І. М. Сорокотягін, І. Я. Фойницький.

Водночас, незважаючи на визнання переважною більшістю вчених можливості проведення допиту обізнаних осіб, серед них також не склалося єдиної думки щодо визначення процесуальної форми його проведення. Зокрема, такі вітчизняні вчені, як А. Ф. Волобуєв, В. Д. Понікаров, В. М. Ревака вважають, що допит ревізорів, спеціалістів та інших обізнаних осіб має проводитися за правилами допиту свідків ${ }^{2}$. Не погоджується $з$ ними О. В. Се-

${ }^{1}$ Див: Семенов В. В. Спеціальні знання в розслідуванні злочинів (зміст, організація використання) : дис. ... канд. юрид. наук : 12.00.09 / В. В. Семенов. - К., 2006. - С. 144; Бондаренко О. О. Процесуальний статус обізнаних осіб та їх правовідносини з дізнавачем і слідчим у кримінальному судочинстві України : дис. ... канд. юрид. наук : 12.00 .09 / О. О. Бондаренко. — Х., 2004. - С. 164.

2 Див: Волобуєв А. Ф. Проблеми методики розслідування розкрадань майна в сфері підприємництва. - Х. : Вид-во Ун-ту внутрішніх справ, 2000. - С. 250; Судебно-бухгалтерская экспертиза : учеб. пособие / [В. Д. Поникаров, И. В. Ялдин, М. В. Стаматина и др.] ; под ред. В. Д. Поникарова. — Харьков : Арсис, 2002. - 
ліна, яка серед форм допиту обізнаних осіб виокремлює допит експерта, спеціаліста-консультанта та обізнаного свідка ${ }^{1}$.

На відміну від наведених точок зору В. Д. Арсеньєв, В. Г. Заблоцький і П. Репешко стверджують, що обізнані особи не можуть бути допитані взагалі, оскільки думки цих осіб відносно як сприйнятих, так і безпосередньо не сприйнятих ними фактів не можуть бути змістом показань свідків ${ }^{2}$.

Досить слушною, на наш погляд, є позиція В. М. Махова, який указує на неприпустимість проведення допиту обізнаних осіб без належної регламентації цієї процедури в законі. Він зазначає, що можливість допиту таких осіб насамперед можна обгрунтувати достатньо об'ємним тлумаченням положення, згідно з яким як свідок може бути викликана будь-яка особа, про яку є дані, що їй відомі або можуть бути відомі обставини, що підлягають доказуванню під час кримінального провадження. Але, як справедливо стверджує вчений, така аргументація не враховує, що свідок є очевидцем фактів, які стосуються безпосередньо справи, а отже, така особа є незамінною. Водночас така вимога не поширюється на експерта або спеціаліста, оскільки ними може бути будь-яка особа, обізнана в певній галузі спеціальних знань ${ }^{3}$.

На нашу думку, при визначенні форм і способів фіксації відомостей, наданих носіями спеціальних знань, слід виходити насамперед з положень чинного КПК України.

Зокрема, що стосується експертів, залучених до кримінального провадження, то позиція вітчизняного законодавця з цього приводу є визначеною. Так, відповідно до ст. 69 КПК України експертом у кримінальному провадженні є особа, яка володіє науковими, технічними або іншими спеціальними знаннями, має право відповідно до Закону України «Про судову експертизу» на проведення експертизи та якій доручено провести дослідження об'єктів, явищ і процесів, що містять відомості про обставини вчинення кримінального правопорушення, i дати висновок з питань, які виникають під час кримінального провадження та стосуються сфери ії знань. Також до обов'язків експерта 3-поміж інших належить обов'язок прибути до слідчого, прокурора, суду й дати відповіді на запитання під час допиту. Цей обов'язок експерта деталізований у ст. 12 Закону України «Про судову експертизу», відповідно до якої судовий експерт зобов'язаний на вимогу особи або органу, які залучили експерта, судді, суду дати роз'яснення щодо даного ним

С. 99-100; Ревака В. М. Залучення фахівців до участі у кримінальному судочинстві / В. М. Ревака // Вісн. прокуратури. - 2003. — № 8. - С. 65-68.

1 Див: Селина E. B. Доказывание с использованием специальных познаний по уголовным делам / Е. В. Селина. - М. : Юрлитинформ, 2003. - С. 82.

2 Див: Арсеньев В. Д. Использование специальных познаний при установлении фактических обстоятельств уголовного дела / В. Д. Арсеньев, В. Г. Заблоцкий. Красноярск: Изд-во Красноярского ун-та, 1986. - С. 74; Репешко П. Участь спеціаліста в судовому розгляді кримінальної справи / П. Репешко // Право України. 1999. - № 9. - С. 78-82.

Див: Махов В. Н. Использование знаний сведущих лиц при расследовании преступлений : монография / В. Н. Махов. - М. : Изд-во РУДН, 2000. — С. 260-268. 
висновку; а також у ст. 356 КПК України, згідно з якою за клопотанням сторони кримінального провадження, потерпілого або за власною ініціативою суд має право викликати експерта для допиту для роз'яснення висновку. Експерту можуть бути поставлені запитання щодо наявності в нього спеціальних знань і кваліфікації з досліджуваних питань (освіти, стажу роботи, наукового ступеня тощо), пов'язаних із предметом експертизи; використаних методик та теоретичних розробок; достатності відомостей, на підставі яких готувався висновок; наукового обгрунтування й методів, за допомогою яких експерт дійшов висновку; придатності та правильності застосування принципів і методів дослідження до фактів кримінального провадження; інші запитання, що стосуються достовірності висновку.

Отже, можна зробити висновок, що відповідно до чинного законодавства показання експерта мають стосуватися тільки зробленого ним раніше експертного висновку. Надання таких показань має відбуватися під час його допиту як експерта. Водночас, з урахуванням того, що будь-який експерт апріорі є спеціалістом, на нашу думку, недоцільно обмежувати надання ним показань виключно роз'ясненням зробленого експертного висновку. У КПК України доцільно закріпити положення щодо можливості висловлення експертом у межах компетенції свєї позиції стосовно обставин, що мають значення для кримінального провадження та встановлення яких потребує застосування спеціальних знань.

Під час здійснення досудового розслідування може виникнути необхідність в отриманні додаткових відомостей від носіїв спеціальних знань, залучених до участі в проведенні процесуальних дій як спеціалістів. Ці відомості можуть бути необхідні як для вирішення організаційних питань (наприклад, щодо визначення переліку документів, необхідних для проведення ревізії або порядку відібрання зразків для проведення експертного дослідження тощо), так і тактичних питань (наприклад, визначення черговості проведення слідчих (розшукових) дій, оцінювання висновків експерта або показань учасників кримінального провадження тощо).

Водночас нерідко виникає необхідність у процесуальному оформленні таких відомостей, зокрема щодо особливостей надання спеціалістом технічної допомоги (фотографування, складення схем, планів, креслень, відбір зразків для проведення експертизи тощо).

Слідчі в подібних випадках досить часто допитують таких носіїв спеціальних знань як спеціалістів, без урахування позиції вітчизняного законодавця, котра стосовно цього є незмінною багато років. Так, відповідно до ст. 65 Кримінально-процесуального кодексу України 1960 р. фактичні дані, що були доказами в кримінальній справі, установлювалися серед іншого показаннями свідка, потерпілого, підозрюваного, обвинуваченого. Разом із тим згідно зі ст. 95 КПК України 2012 р. показаннями є відомості, які надаються в усній або письмовій формі під час допиту підозрюваним, обвинуваченим, свідком, потерпілим, експертом щодо відомих їм обставин у кримінальному провадженні, що мають значення для цього кримінального провадження. 
Отже, коли порівнювати зазначені положення між собою, то можна побачити, що перелік учасників кримінального провадження, які мають право давати показання, за чинним КПК України, було розширено за рахунок таких носіїв спеціальних знань, як експерти. Проте ні в Кримінально-процесуальному кодексі України 1960 р., ні в чинному КПК України законодавець не передбачив серед суб'єктів надання показань спеціалістів.

У ст. 95 КПК України зазначено, що висновок або думка особи, яка дає показання, можуть визнаватися судом доказом, лише коли такий висновок або думка корисні для ясного розуміння показань (їх частини) і грунтуються на спеціальних знаннях у розумінні ст. 101 цього Кодексу. Аналіз змісту цих статей КПК України дає підстави зробити висновок, що вони також поширюються виключно на експертів.

На нашу думку, наведені положення КПК України не повною мірою відповідають вимогам сьогодення, адже спеціалісту, так само, як і згаданим іншим учасникам кримінального провадження, також можуть бути відомі обставини, що мають значення для кримінального провадження. Ураховуючи викладене, статті 71 та 95 КПК України потребують унесення змін.

Аналіз положень чинного КПК України дозволяє встановити, що поряд 3 терміном «показання» законодавець використовує термін «пояснення». Так, відповідно до п. 6 ч. 3 ст. 69 КПК України експерт має право одержати винагороду за виконану роботу та відшкодування витрат, пов'язаних із проведенням експертизи та викликом для надання пояснень чи показань, у разі, якщо проведення експертизи не є службовим обов'язком особи, яка залучена як експерт. Що стосується спеціаліста, то згідно з ч. 3 ст. 71 КПК України сторони кримінального провадження мають право під час судового розгляду заявляти клопотання про залучення спеціаліста або використання його пояснень і допомоги.

Слід зауважити, що на відміну від терміна «показання», законодавець не надав визначення терміна «пояснення». Можливість проведення цієї процесуальної дії в загальних рисах передбачена ст. 95 КПК України, відповідно до якої пояснення може одержувати від учасників кримінального провадження за їх згодою навіть представник сторони захисту. Аналіз вітчизняного кримінального процесуального законодавства дає підстави зробити висновок, що за своїм змістом пояснення є досить схожими з показаннями, однак на відміну від останніх не $\epsilon$ джерелом доказів. 3 огляду на викладене отримання пояснень від учасників кримінального провадження, зокрема від носіїв спеціальних знань, майже не використовується на практиці стороною обвинувачення або судом.

Крім того, відповідно до ст. 71 КПК України спеціаліст може надавати консультації з питань, які потребують відповідних спеціальних знань і навичок. Як свідчить практика, подібні консультації спеціалістів надаються на стадії підготовки до слідчих (розшукових) дій та $€$ засобами підвищення їх ефективності. При цьому законодавцем також не визначено як зміст терміна «консультації», так і порядок процесуального оформлення їх надання та шляхи подальшого використання в кримінальному процесі. Водночас аналіз 
положень чинного КПК України дозволяє зробити висновок, що такі консультації спеціалістів, як і пояснення, також не є джерелами доказів.

Деякі слідчі намагаються «обійти» виокремлені нами недоліки чинного кримінального процесуального законодавства шляхом оформлення наданих спеціалістами показань (у тому числі їх власні міркування та судження стосовно певних обставин кримінального провадження) у вигляді повідомлень, зауважень, доповнень, а також додатків до протоколів слідчих (розшукових) та інших процесуальних дій (крім допиту), учасниками яких вони були. На нашу думку, такий підхід не суперечить чинному КПК України та може мати місце, принаймні до моменту вирішення зазначених проблем на законодавчому рівні. Адже оформлені таким чином відомості сприйматимуться судом не як показання, а як частина змісту протоколів процесуальних дій, які згідно зі ст. 99 КПК України є документами, а отже - джерелом доказів.

Однак для слідчих залишається актуальним визначення шляхів отримання відомостей від носіїв спеціальних знань, які раніше не брали участі в кримінальному провадженні ні як експерти, ні як спеціалісти, з метою подальшого використання наданих ними відомостей у процесі доказування. Вирішення цієї ситуації на думку багатьох учених убачається в законодавчому закріпленні можливості допиту таких осіб, як обізнаних свідків ${ }^{1}$.

Проте, на нашу думку, виокремлення нової категорії свідків не є доцільними ні з етимологічної, ні з процесуальної точок зору. Так, відповідно до ст. 65 чинного КПК України, свідком є фізична особа, якій відомі або можуть бути відомі обставини, що підлягають доказуванню під час кримінального провадження, і яка викликана для давання показань. У свою чергу обставини, що підлягають доказуванню, зазначені в ст. 91 КПК України, та вони не є тотожними відомостям спеціального характеру, що мають значення для кримінального провадження, якими володіють обізнані особи. Крім того, визначення такої категорії учасників кримінального провадження, як «обізнані свідки», може створити хибне уявлення їх ролі в кримінальному процесі, адже вони не є (та й не можуть бути) свідками навіть у розширеному тлумаченні цього терміна.

Уважаємо за доцільне доповнення чинного КПК України положенням щодо можливості отримання показань від обізнаних осіб. До останніх належатимуть будь-які особи, які володіють науковими, технічними або іншими спеціальними знаннями чи навичками застосування технічних або інших засобів та залучаються до кримінального провадження як експерти чи спеціалісти, або з приводу обставин, що мають значення для кримінального провадження, установлення яких потребує застосування спеціальних знань.

Підсумовуючи наведене, можна зробити такі висновки:

1. 3 метою законодавчого закріплення права спеціаліста давати показання викласти ч. 1 ст. 95 КПК України в такій редакції: «Показання - це відо-

${ }^{1}$ Див.: Семенов В. В. Указ. праця. - С. 144; Стахівський С. М. Показання свідка як джерело доказів у кримінальному процесі : автореф. дис. на здобуття наук. ступеня канд. юрид. наук : спец. 12.00 .09 «Кримінальний процес та криміналістика; судова експертиза» / С. М. Стахівський. - К., 1996. - С. 11. 
мості, які надаються в усній або письмовій формі під час допиту підозрюваним, обвинуваченим, свідком, потерпілим, експертом та іншими учасниками кримінального провадження щодо відомих їм обставин, що мають значення для цього кримінального провадження».

2. Відповідно в п. 2 ч. 5 ст. 71 КПК України після слова «пояснення» необхідно додати словосполучення «та показання».

3. Доповнити КПК України статтею:

«Стаття $227^{1}$. Допит обізнаної особи

1. На вимогу особи або органу, які залучили експерта, судді, суду експерт зобов'язаний з'явитися та дати показання щодо роз'яснення зробленого ним експертного висновку.

2. На вимогу особи або органу, які залучили експерта, судді, суду спеціаліст зобов'язаний з'явитися та дати показання щодо особливостей своєї участі в проведенні процесуальної дії.

3. У разі необхідності з'ясування обставин, що мають значення для кримінального провадження, установлення яких потребує застосування спеціальних знань, як обізнані особи можуть бути допитані будь-які особи, які володіють науковими, технічними або іншими спеціальними знаннями чи навичками застосування технічних або інших засобів. Отримані в такий спосіб показання можуть використовуватися в процесі доказування тільки в сукупності з іншими наявними доказами та самостійного доказового значення не мають».

\section{ПРОБЛЕМНЫЕ ВОПРОСЫ, КАСАЮЩИЕСЯ ПОЛУЧЕНИЯ ПОКАЗАНИЙ ОТ СВЕДУЩИХ ЛИЦ}

Фастовец В. А.

Исследованы некоторые вопросы, касающиеся получения показаний от сведущих лии (носителей специиальных знаний) в уголовном производстве. Выявлень недостатки правоприменительной деятельности в отношении процессуального оформления таких показаний, противоречащих требованиям действующего уголовного прочессуального законодательства. Дань собственные предложения по внесению изменений в Уголовный процессуальный кодекс Украины.

Ключевые слова: Уголовный прочессуальный кодекс Украины, допрос, эксперт, специалист, сведущий свидетель, сведущее лицо.

\section{PROBLEMATIC ISSUES OF TAKING EVIDENCE FROM KNOWLEDGEABLE PERSONS}

\section{Fastovets $V . A$.}

In paper attention is accented on the lacks of legal regulation of certain issues on the use of special knowledge in the domestic criminal trial. In particular, it concerns the features of using information provided by expert or specialist in the pre-trial investigation or during the judicial consideration, who were involved in the investigation (search) or other procedural actions, as well as by the carriers of special knowledge who previously 
were not involved in the criminal proceeding. This information is used by an investigator or by a judge for the resolutions on the issues of organizational and tactical nature, but the necessity of using such information in the process of evidence arises quite often. The above is interrelated with the question of «introducing» such information to the criminal proceedings, that is, to the procedure of the procedural registration. The study of law enforcement practice, as well as the scientific papers of the experts on process, established no single approach to this issue. The paper analyzes the provisions of the Criminal Procedural Code of Ukraine, during which there are revealed a number of lacks, namely the restriction to give expert testimony exclusively on the report provided by him; exclusion of a specialist from the number of the subjects who can provide a testimony; absence of a clear regulation of giving evidence form by the carriers of special knowledge. The author substantiates the unreasonableness of introducing such a subject of the criminal proceeding as a «competent witness» and presents the arguments in favor of the supplement to the Criminal Procedural Code with the provision on the possibility of obtaining testimony from knowledgeable people. The author proposes appropriate changes to Criminal Procedure Code of Ukraine relative to extending the list of giving testimony subjects in the criminal proceedings.

Keywords: Criminal Procedural Code of Ukraine, questioning, expert, specialist, competent witness, knowledgeable person.

\section{ОБСТАВИНИ, ЯКІ ПІДЛЯГАЮТЬ ДОКАЗУВАННЮ В КРИМІНАЛЬНОМУ ПРОВАДЖЕННІ ПРИ РОЗСЛІДУВАННІ ЗЛОЧИНІВ, ПОВ'ЯЗАНИХ ІЗ ПОЖЕЖАМИ}

Досліджено обставини, які підлягають доказуванню в кримінальному провадженні при розслідуванні злочинів, пов'язаних із пожежами. Зазначено, щзо до обставин, які характеризують подію пожежі як злочин, крім загальних (місие, час та ін.), необхідно віднести й такі дані: обстановку, яка передувала пожежі; обставини виникнення та розвитку пожежі; обстановку, що склалася після пожежі.

Ключові слова: обставини, які підляають доказуванню; предмет доказування, кримінальне провадження, розслідування злочинів, злочини, пов'язані з пожежами.

Обставини, що підлягають доказуванню при розслідуванні злочинів, у структурі окремої криміналістичної методики мають велике значення. Знання предмета доказування дозволяє особі, яка проводить розслідування, швидко й правильно спланувати та цілеспрямовано провести досудове розслідування. Особливо важливим є знання таких обставин при розслідуванні злочинів, пов'язаних із пожежами, де об'єктом пізнання є певна поведінка людей, механізм якої супроводжується діями вогню.

(C) Колесніков В. В., 2016 